PUATICATIONS WHICH, IN WHOLE OR IN FADT, ADE THE PESULT OS ROFI DONE BY THE ENGINEERING NECHAIIOS SECTIOR

$$
-\ldots-\ldots
$$

The publications for which a price is fivan may be obtained from the Superintencent of Documents, Goverrment Frinting Cffice: Washington, D. C.

The Public Library in most of the lare cities in this coun try are repositories for goverment putlications. The Exrecu of Standards papers can, in most cases, be fourd in the libraiy in your city even if the supply available for distribution is exhizustea.

The following aboreviations are used for the publicaticns:

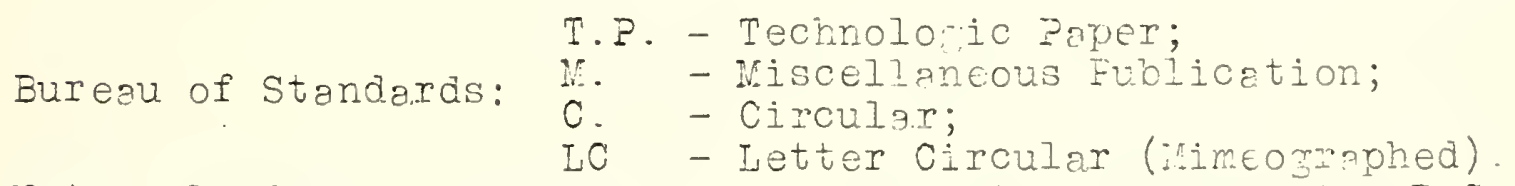
National Advisory Committee for Aeronatics, Washington,D.C.N.A.C.A.

The numbers following the subject are the file numbers. For title of publication see Chronological list which follows the Subject List.

\title{
SUBJECT LIST
}

Airships: 81, 103.

Aluminum: 103.

Calibration of Testing Machines: 104.

Duralumin: 103.

General: 90, 99, 100, 102.

Hardness: 104.

Impact: 92 .

Safes, burdar-resisting: 101.

Tile, hollow blag.: 93.

Welding and cutting: 94, 95, $96,98$.

Columns: 97.

\section{CHFONOLOGICAL LIST - 1925 -}

90 - Publications of the Engineering liechanics Section, IC 166.

91 - Inertia Factors of Ellipsoids ror Airship Desich,

L. B. Tuckermar, I.A.C.A.Report iso. 210,5 cents. 

Supplement to LC 166 -2- Axril 13, 2826.

92 - vomparative Slow Bend and Impact Notched Ear Tests of Some retals,

S. I. Petrenko,

T. P. 289, Aumust, 1925,20 cents.

93 Tests of Follow Tile and concrete slobs reinforced in One Direction,

D. E. Parsons, $f_{2}$. if. Stanr,

$$
\text { I. P. } 231, \mathrm{Aug} \text {. 12, İ25, } 25 \text { conts. }
$$

94 - Proeress Feport No. 1, Committee on Belder Fail Joirts

(This is not a Eureau publicetion; it a y bz ortaired by purchasing from the American Eureau of Veldine, 29 Viest 39th St., New Yoris City).

95 - Progress Report No. 2, Committee on Welacd Rail Joirts (This is rot a Eureau publication; it may be outained by purchasing from the American Eureau of welding, 29 Viest 39 th St., New York City).

96 - Proeress Report $\mathbb{1}$ - 3, Committee on Welded Rail Joints (This is not a. Bureau publication; it may be obtaincd by purchasing from the American Bureau of Wclding, 29 West 39 th St., New York City).

97 - Research and Experimental Tests in Connection With the Design of the Pridge Over the Delaware River Between Fhiladelphia and camden, Engineers and Engineering, Ausust, 1925, vol. XLII, No. 8, p. 197. - 1926 -

98 - Tests on Vielded Pressure Vessels, L. H. Roller, Refrigerating Engincering, January, 1926, p.215.

99 - Annual Report of the Director, N. 39.

100 - Testing Leboratories Equipped for Ifchanical Tests of Metals and other Engineering Noterials, LC 191, January 21, 1926.

101 - U.S.Government Naster Specification for Burglar-Resisting Safes, F.S.B. No. 363, Decerber 12, 1925.

102 - Research Associates at the Bureau of standards, C.296.

103 - Properties of Duralumin (Corrosion), Engineering News-Record, iTov. 26, 1925, No. 22, p. 862, 863; Dec. I7, 1925, vo1. 95, No. 25, p. 979, 1000, 1001, 1006; Jan. 7, 1926, vol. 96, ㄲo. 1, p. 1, 34 .

104 - Elastic Ring for Verification of Brinell Haraness Testing Machines, Transactions, A.S.S.T. (Ar.Soc.SteeI Treatirs, 4600 Prospect Ave., Cleveland, 0.) March, I8:5, vol. IX, No. 3, p. 420 . 
